\title{
THE DETERMINANTS FOR SHOPPING CART ABANDONMENT
}

\author{
Leonardi Levino Yusuf ${ }^{1}$, Dewi Tamara ${ }^{2}$, Nugroho J. Setiadi ${ }^{1}$ \\ ${ }^{1}$ Business Management Program, Management Department, BINUS Business School Master Program, \\ Bina Nusantara University, Jakarta Indonesia 11480 \\ ${ }^{2}$ Executive in Strategic Management Program, Management Department, BINUS Business School \\ Master Program, Bina Nusantara University, Jakarta Indonesia 11480
}

\section{Article Information}

Received: 8 June 2021

Accepted: 3 August 2021

Published: 30 September 2021

DOI: $10.33555 / \mathrm{embm.v8i2.178}$

\section{Corresponding Author:}

Dewi Tamara

Jakarta, Indonesia

Email: dtamara@binus.edu

ISSN $2338-8854$

eISSN 2620-9918

\begin{abstract}
This paper has the objective to investigate the determinant that leads to shopping cart abandonment. Factors are perceived cost $(P C)$, complicated checkout (CC), Entertainment Motivation (EM), Emotional Ambivalence (EA), Information Overload over the Product (IA). This paper use quantitative study, using a sample of 117 respondent consist of men and women who have ever done shopping cart abandonement. The hypotheses were tested by path analysis in Structural Equation Modelling.

The study shows interesting findings. First the Perceived Cost (PC), Complicated Checkout (CC), Emotional ambivalence (EA), and Information Overload (IO) have positive effect of shopping cart abandonment but not significant. Second, Entertainment Motivation (EM) has a positive and significant effect on shopping cart abandonment. The result explained that the customer did not perceive the proposed variables as determinant factors to abandon the shopping cart. The only variable matter is entertainment motivation, where the customer liked to put all shopping goods to their cart. The contribution of this research is to improve the content of information and create positive ambivalence for the customer in their page.
\end{abstract}

Keywords: Emotional Ambivalence, Entertainment Motivation, Information Overload, Shopping Cart Abandonment 


\section{Introduction}

In today's digital era, technological developments in Indonesia are growing very fast. With today's technology, it is increasingly easier to solve human problems in carrying out daily activities that affect changes in behavior patterns, activities, and lifestyles of the community. Today, many retail companies are starting to move from conventional to online. So that the marketing strategy must also adapt to the situation, one of which is by involving marketing with social media and websites. For example, using Instagram and Facebook for advertising purposes.

The development of e-commerce in Indonesia from 2015 has continued to increase until now. "Marketplace" is the most common e-commerce concept in Indonesia. According to Opiida (2014), Marketplace is an online media based on websites on the internet to conduct online transactions between two parties. Buyers can find various suppliers to get the products they want at market prices. Meanwhile, sellers/suppliers can find out companies that need services or products offered in the marketplace. Currently, there are five (5) largest marketplaces in Indonesia, namely Shopee, Tokopedia, Lazada, Blibli, and Bukalapak. In this marketplace, buyers can search for the items they want, such as clothes, shoes, electronics, cosmetics, facial care, and so on.

The existence of a marketplace can indeed make it easier for buyers to shop, only by using an application or website the buyer can get the desired item, but the convenience of this marketplace can be a problem for sales. One of the biggest problems in the global marketplace is the high rate of shopping cart abandonment. One important problem in online retail is shopping cart abandonment, which is a condition where the buyer just abandon their shopping cart and do not finish the transaction. According to Cho (2004) for every successful online transaction, almost four times the number is a transaction that is abandoned or becomes a shopping cart abandonment. A higher level of shopping cart abandonment reflects an increase in the number of unrealized sales.

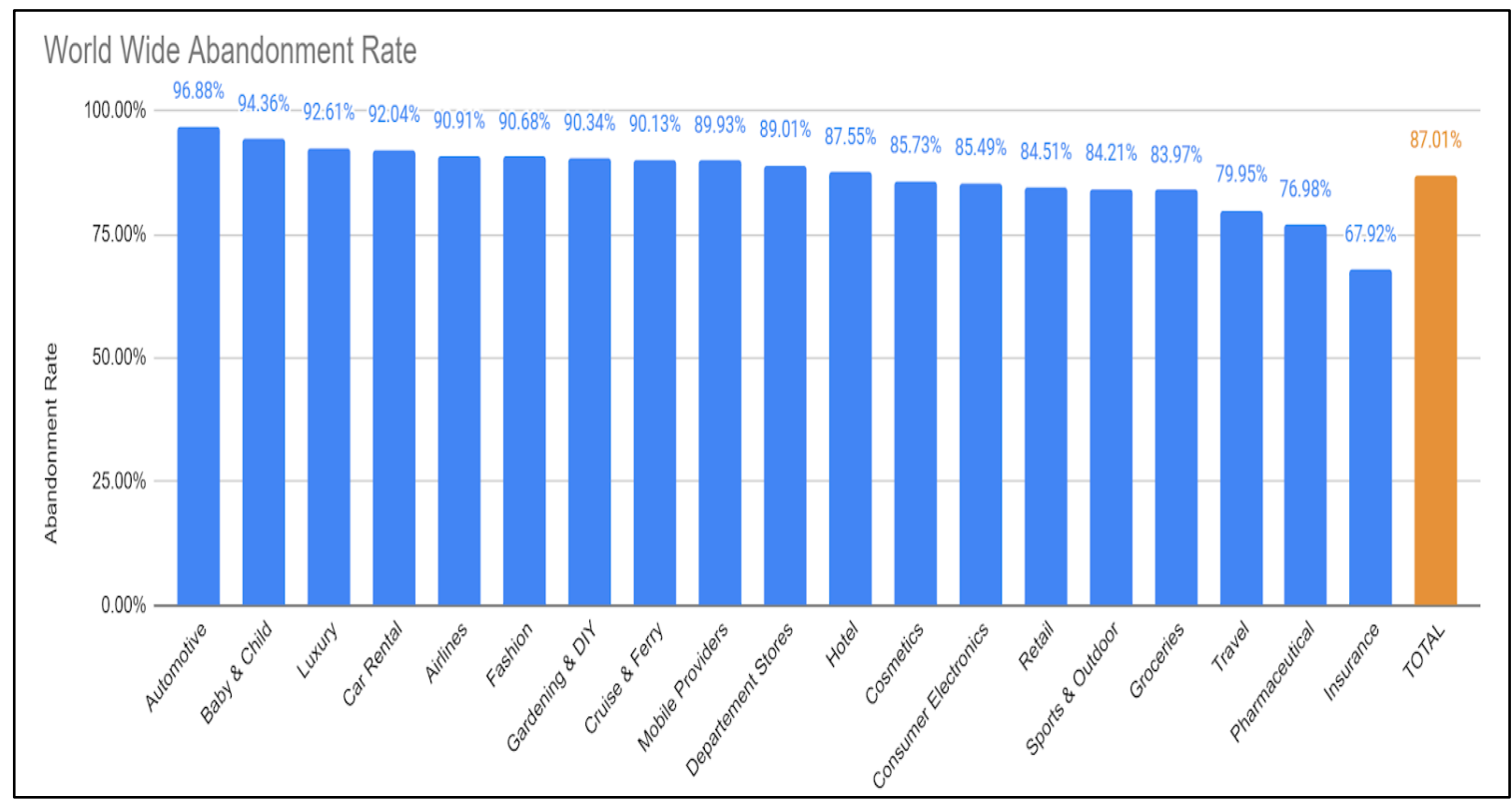

Figure 1. World Wide Abandonment Rate

Source: statista.com (June, 2020) 
Based on data from Statista.com, it can be seen that the average level of shopping cart abandonment in all sectors is $87.01 \%$, so it can be concluded that the level of shopping cart abandonment in the world is very high. Based on the chart above, automotive has the highest rate of all, while insurance has the lowest rate.

According to the 2019 Global Digital Report, Indonesia dominates the list of countries in the world that love to buy goods online. In February 2019, 76\% of Indonesia's population was proven to shop online via smartphones. As many as $81.3 \%$ use the internet for chatting, while $77.4 \%$ admit only for browsing. Now, Indonesian e-commerce such as Tokopedia and Bukalapak are growing in various ways. This activity has changed the way consumers previously had to come to the store to see goods, so all they need to do is browse for the goods they want wherever they are.

The Indonesia Millennial Report (IMR) in 2019 also found that $12.2 \%$ of Indonesian millennials access online shopping. As many as $59.7 \%$ of the millennial generation also look for price comparisons online before making a purchase. Not only prices, but they are also looking for information about product or service features, as well as reviews from customers.

The 2019 IMR qualitative study also shows that many millennial generations are disappointed when shopping online. However, this did not make them give up. Instead, they chose to look for other online sellers. This behavior is of course important for e-commerce players and the government to pay attention to make consumer satisfaction regulations.

According to IDN Times, there are five things that are taken into account by Twitter users in Indonesia when shopping online, namely: free shipping, $56.5 \%$; $55.6 \%$ discount or coupon; $54.1 \%$ from other buyer reviews, $41 \%$ from positive comments on social media; and easy policy $35.4 \%$.

The gap in this journal are the number of research items is still small, so it still does not represent the independent and dependent variables and also the number of previous studies on shopping cart abandonment is still small, causing the reference of this study to be narrow.

\section{Literature Review}

Shopping cart abandonment can still occur entirely depending on the checkout process being able to fulfill customer desires demonstrated by their experience up to a point. According to Rajamma et al. (2009), if the checkout process does not match expectations, consumers tend to feel disappointed, even if there are small errors. If a customer needs to stay longer at checkout, the transaction will start to look dangerous, or the final transaction process looks awkward, which can lead to shopping cart abandonment, even though the customer was previously happy with his involvement in the e-commerce website up to that point.

According to Kukar-Kinney (2009). without making a purchase, simply putting items in the shopping cart is a way of entertaining oneself for online shoppers. The type of buyers may feel the sensation of performing a shopping ritual and satisfy their impulse to shop without having to buy and spend. The effort from online retailers to make their sites interesting and attractive does not automatically improve the buying or transaction.

Emotional ambivalence describes the process of forming behavior in which beliefs or thoughts that affect emotionally both beneficial and detrimental, thus shaping a person's behavior. This variable can explain high involvement behavior. In this study, emotional ambivalence measure focuses on shopping cart abandonment behavior by buyers, not browsers who do not intend to complete the purchase. 
Priester and Petty (2001) state that customer will judge before influence-oriented ambivalence and categorize them both as intrapersonal and interpersonal conflicts. The conflict from intrapersonal refers to measure a person's positive and negative reactions to an object/item, whereas interpersonal conflict describes the extent to which disagreement between oneself and others is significant. The existence of emotional ambivalence will bring out feelings of doubt in a person. Cho et al. (2006) describe online shopping hesitation as "delaying the purchase of a product by increasing processing time before making a final product purchase on the Internet." There are three types of online hesitation: overall shopping indecision, shopping cart abandonment, and button-click hesitation for final payment. For example, perceived uncertainty is closely related to shopping cart abandonment, but not related to doubts when making payment. Doubts. at checkout and shopping cart abandonment are different steps.

\subsection{Previous Research}

\subsubsection{Shopping Cart Abandonment}

In this literature, shopping cart abandonment can be found in two ways, as a behavior variable (Cho, 2004; Cho et al., 2006; Moore and Mathews, 2006) and as a technology variable ( $\mathrm{Li}$ and Chatterjee, 2005). In this literature review, the behavioral variables will be the main focus. Cho (2004) conducted a study on people's attitudes towards current e-shopping and past e-shopping behavior, with variables of frequency (how often visitors come back to the site) and recency (length of time in days, since a particular visitor last visited the site) in a purchase and the amount of money spent, the results of the study show that attitudes towards current and past eshopping do have a significant effect on cancelling the intended transaction. Time was not considered a factor in the study (Cho, 2004), but other researchers (Cho et al., 2006) found that the explanations behind procrastination significantly influence stag-nant internet shopping that includes shopping cart abandonment. There are three-factor variables: perceived uncertain-ty factors, media/channel innovation factors, and contextual factors added to the explanation behind delay when combined with customer types, it will all influence online shopping indecision (Cho et al., 2006). Moore and Mathews (2006) examined shopping cart abandonment because it is influenced by perceived risk, particularly performance risk. Previous research explained that exit in online retails send signals there is a risk of shopping cart abandonment (Moore and Mathews, 2006).

\subsubsection{Perceived Cost}

Transaction costs are shown to significantly affect the size of online shopping (Wu et al. 2014), including shopping cart user behavior (Magill, 2005). In addition, on the web, compared to offline, buyers are more likely to consider the value offered and expect lower overall costs (Xia and Monroe, 2004); That is why online shoppers can do more searches to find suitable costs. If the cost of the product is higher than projected, online shoppers are willing to look for products with a higher value/quality of goods. At present, their exploration efforts will increase, and they will undertake more brands and inspections of shopping cart items (Kukar-Kinney and Close, 2010). A large number of merchandises sold at different prices will help buyers have choices of varying value/quality of goods, thus enabling them to make the right decisions.

The results of Xu's (2015) study show that perceived cost and perceived risk do not directly affect cart abandonment but there is an indirect effect on cart abandonment through organizational mediators and product research in baskets. This means that the higher the perceived cost or perceived risk, the more likely consumers are to organize and research the products in their baskets. In their research, the results showed that perceived cost and perceived 
risk have a positive effect on shopping cart abandonment.

\subsubsection{Complicated Checkout}

Based on the results of research by Rajamma (2009), it is stated that sellers should try to make the checkout process as easy as possible so that shopping cart abandonment can be reduced. So it can be concluded that the results of their research show that the more complicated the checkout process, the more shopping cart abandonment will increase, in other words, a complicated checkout process has a positive effect on shopping cart abandonment.

\subsubsection{Entertainment Motivation}

According to Novak et al. (2003); Wolfinbarger and Gilly (2001), consumers may shop online with the motive of looking for entertainment and also organize goods that are likely to be purchased. The motive for seeking entertainment includes finding goods and buying these items for fun, or to get rid of boredom. (Moe 2003; Wolfinbarger and Gilly 2001) or as a mediator to kill time or as an escape (Mathwick et al. 2001). So, consumers who are looking for entertainment in shopping may put the desired item in the basket because of hedonic habits. Usually, consumers who are looking for entertainment (Novak et al. 2003; Wolfinbarger and Gilly 2001) see shopping as fun and can experiment to get the desired product or service. (Bellenger and Korgaonkar 1980; Holbrook and Hirschman 1982).

According to Kukar-Kinney (2009), using a shopping cart for entertainment is positively related to shopping cart abandonment and negatively with the overall frequency of online purchases. However, given the entertainment value it provides, consumers who use their baskets for fun or to get rid of boredom can still spread positive word of mouth about online retailers and their experiences on their websites, even if they choose not to buy.

\subsubsection{Emotional Ambivalence}

The effect of emotional ambivalence on shopping cart abandonment was also found to be a positive and significant variable on shopping cart abandonment (Huang, 2018). College students are more likely to discard their chosen items from their online shopping cart if they spend more time on the Internet, because there are too many choices they tend to get confused, and have previously had bad experiences in online shopping. They don't checkout, which increases the shopping cart abandonment rate.

\subsubsection{Information Overload Over the Product}

In Cho's (2006) research results, it is proven that students who understand very well about prices, want to make price comparisons with their website or physical retail stores, and feel that the website is unreliable because it requires too much personal information or has a complicated checkout process. Cho (2006) also states that price comparisons in shopping are the strongest factor in shopping cart abandonment.

\subsection{Hypothesis Development}

\subsubsection{Perceived Cost to Shopping Cart Abandonment}

Another major cause of shopping cart abandonment has to do with the economy, for example, high fees, postage costs, small discounts, and so on. (eMarketer 2016; Nicholls 2014). The marketplace has a postage system that is paid by the buyer.

If the buyer is sensitive to the total cost of all items in the shopping cart, including postage costs, taxes, etc. Most Internet users expect online retailers to offer their goods at lower prices, but the overall cost of the final order may deter or discourage buyers from buying (Li and Chatterjee 2006; Magill 2005; Xia and Monroe 2004). 
Buyers who are sensitive to the total cost of an order will influence the online shoppers' decision to wait until the lower price is found for at least one item in the basket, be it in the same or a different store. The third the price of the goods exceeds the reference price, the buyer will expect the lower purchase price to be available elsewhere or to be available soon. The number of shopping carts increases without being balanced with the increasing number of checkouts causing the level of shopping cart abandonment to increase.

H1: Perceived cost has a positive and significant effect on shopping cart abandonment

\subsubsection{Complicated Checkout Process to Shopping Cart Abandonment}

When consumers have entered goods into their shopping cart, and they will continue the payment transaction (checkout). Usually at this stage consumers find it difficult to make payments, such as there are no clear steps from the online shop on how to make payments or few payment options such as bank transfers that are provided are limited, or cannot pay other than by using a bank transfer. These difficulties will diminish the desire of buyers to complete the transaction, so that shopping cart abandonment increases because the transaction is not completed.

H2: Complicated checkout process has a positive and significant effect on shopping cart abandonment

\subsubsection{Entertainment Motivation Lead to Shopping Cart Abandonment}

Buyers who do shopping just for entertainment will put the desired item into the shopping cart to please themselves, and to get rid of boredom, without any desire to complete the transaction (checkout). So that it will increase the Shopping Cart Abandonment.
H3: The increase in entertainment motivation has a positive and significant effect on shopping cart abandonment

\subsubsection{Emotional Ambivalence to Shopping Cart Abandonment}

Ambivalence can create a person to experience positive and negative feelings simultaneously, negative feelings will be more influential because of the negative effects that result (Kanhouse \& Hanson, 1972). This uncomfortable feeling will generate negative emotions from consumers. This emotion will influence consumer decisions. Emotional ambivalence will also create feelings of discomfort and aversion (van Harreveld, van der Pligt, \& de Liver, 2009). A bad shopping experience from previous shopping will also be able to change a person's view of purchases in a shopping cart in terms of satisfaction levels (Chea \& Luo, 2008) and brand attitudes (Chang, 2011). With the existence of emotional ambivalence, consumers will make an initial purchase (put in a shopping cart), but there is still a possibility that consumers will not finish the shopping, because there is a feeling of doubt caused by the same positive and negative feelings.

H4: Emotional ambivalence has a positive and significant effect on shopping cart abandonment

\subsubsection{Information Overload Over the Product Leading to Shopping Cart Abandonment}

Buyers will delay the purchase decision or hesitate to get more information on the product of their choice. On the other hand, consumers will feel less confident when making decisions when they get new information. However, if they have too much information about the product they intend to buy, they may experience confusion or difficulty making a decision. Especially on the internet, consumers tend to experience too much information, because on the internet we can find all kinds 
of information for various brands at different selling prices. Too much information will confuse consumers, and delay checkout, resulting in increased shopping cart abandonment

For example, online shopping has no limitations in terms of product displays, which makes the shelf space in an online store unlimited, allowing online stores to offer a very large number of alternatives in a product category. Although access to a wide variety of products in one category may be desired by consumers, they may not be able to process all the information available because of a person's intellectual limitations.

H5: Information overload over the product has a positive and significant effect on shopping cart abandonment

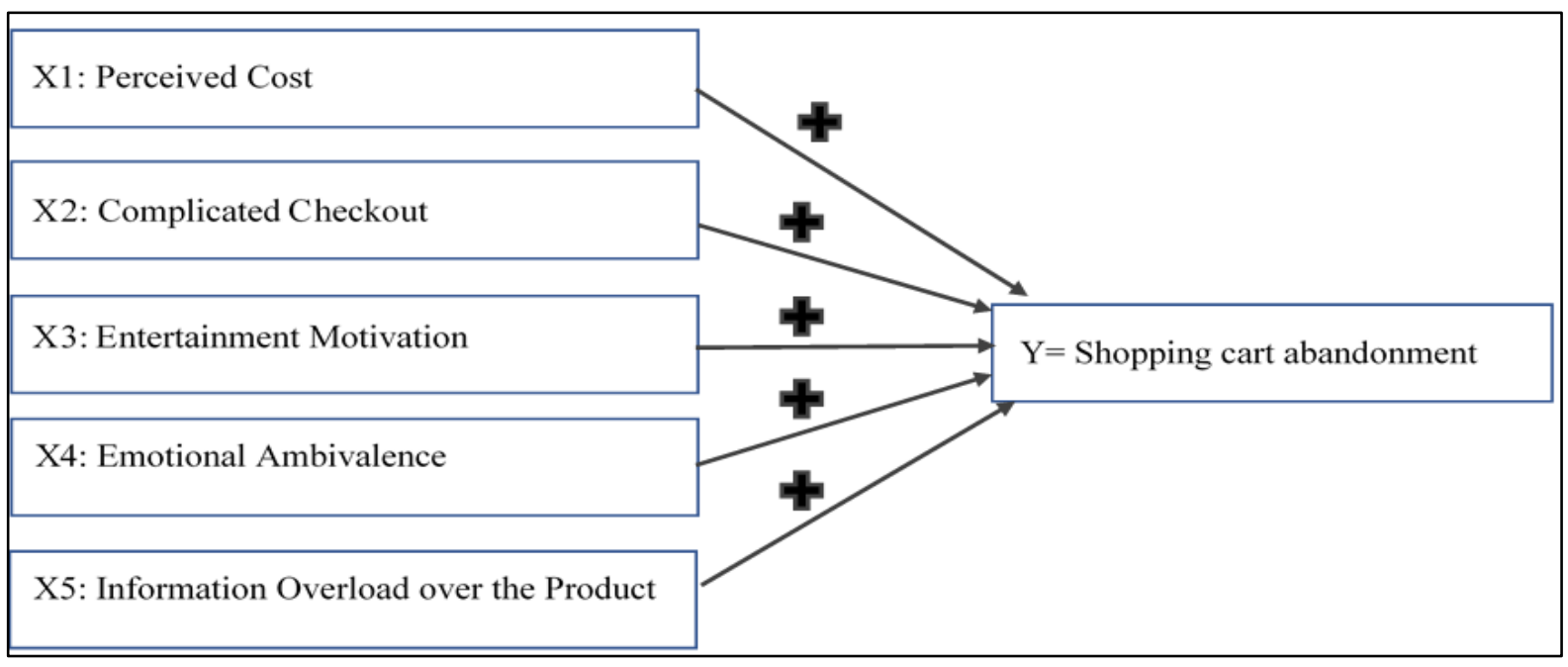

Figure 2. Research Model

\section{Research Methodology}

This study discusses the factors that can influence shopping cart abandonment. Most of the respondents from the online survey were drawn from the Jakarta area. The target respondents for this online survey are 250 respondents who have done shopping cart abandonment from online marketplaces. The questionnaire contains 21 questions that have a relationship with existing variables. Data were taken in January 2020.

From previous research related to shopping. The questionnaire contains questions about several factors related to the author's hypothesis. These factors are perceived cost, complicated checkout process, entertainment motivation, emotional ambivalence, and information overload over the product. Respondents will answer questions in a 5-point Likert scale with a distance of strongly disagree (1) to strongly agree (5). In the questionnaire, there are three different sections, section one contains the demographics of the respondents, section two contains shopping cart abandonment, and section three contains the respondents' reasons for shopping cart abandonment.

Perceived Cost. To summarize perceived cost, it is based on variables adapted from $(\mathrm{Xu}, 2015)$. The variables include the perception of the size of the discount, postage, and the total price.

Complicated Checkout Process. To discuss a complicated checkout process, it is based on variables adapted from (Rajamma et al. 2009). Variables include complex transaction processes and complicated payment steps. 
Entertainment Motivation. To discuss entertainment motivation, it is based on variables adapted from (Kukar-Kinney and Close 2010). Variables include putting things in for personal enjoyment and stuffing them when they're bored.

Emotional Ambivalence. To discuss emotional ambivalence, based on variables adapted from (Huang 2018). Variables include feeling hesitant to checkout and include items based on mood.

Information Overload over the Product. To discuss information overload over the product, it is based on variables adapted from (Cho 2006). Variables include comparing prices with other stores and entering items of the same type in order to choose the best product.

Cart Abandonment. To summarize shopping cart abandonment, based on variables adapted from (Huang 2015). The variables used to evaluate shopping cart abandonment will be based on the respondent's answers to shopping cart abandonment.

\section{Result and Discussion}

The distribution of respondents by gender can be seen in Table 1 below.

Table 1. Distribution of Respondents Gender

\begin{tabular}{cccc} 
No & Gender & $\mathbf{n}$ & $\%$ \\
\hline 1 & Men & 53 & $42.7 \%$ \\
2 & Women & 71 & $57.3 \%$ \\
\hline & Total & $\mathbf{1 2 4}$ & $\mathbf{1 0 0 . 0 \%}$
\end{tabular}

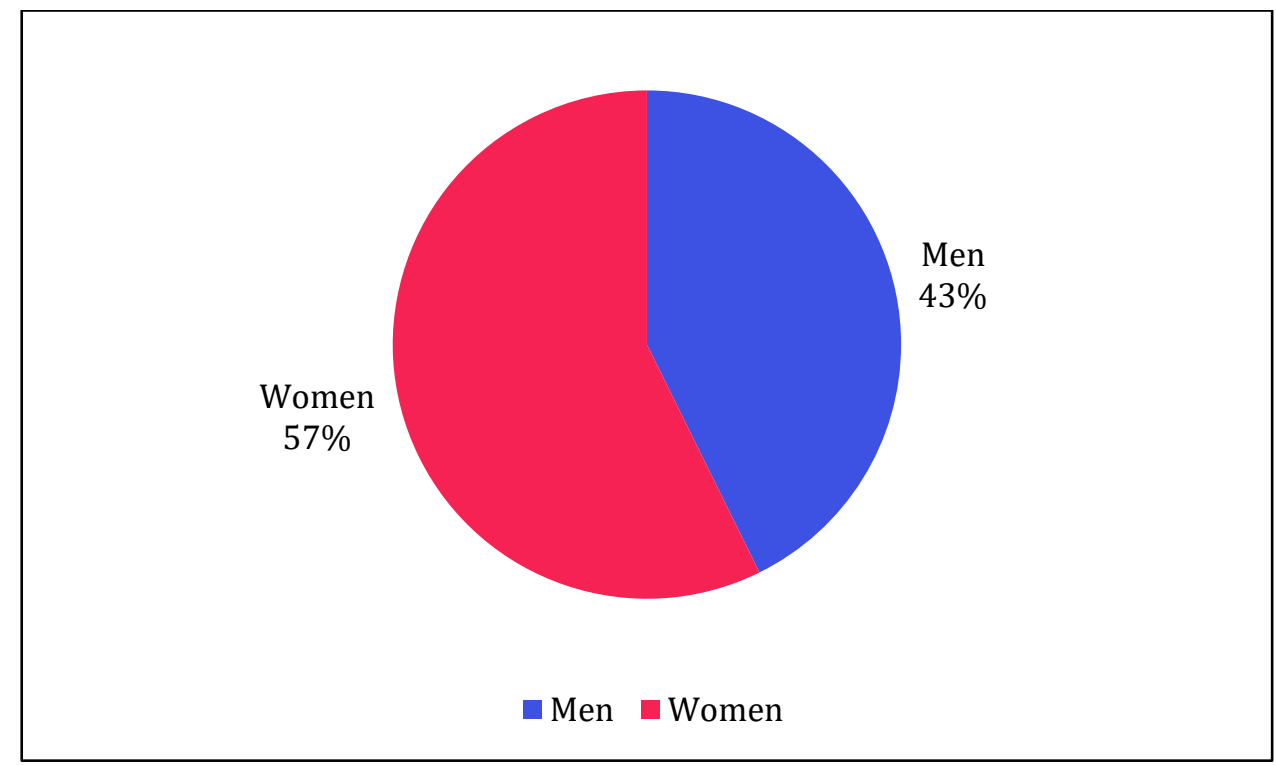

Figure 3. Graph of Respondents Gender

Based on Table 1 and Figure 3 above, which describes the characteristics of respondents by gender, it can be seen that the number of male respondents was 53 or $42.7 \%$. Meanwhile, for female respondents as much as 71 or $57.3 \%$. 
In this study, the authors classified the age of the respondents into 4 categories, namely:
- 15-17 years old

- 18-24 years old

- 25-29 years old

- Age $>30$ years

Table 2. Age Distribution of Respondents

\begin{tabular}{cccr} 
No & \multicolumn{1}{c}{ Age } & $\mathbf{n}$ & \multicolumn{1}{c}{$\%$} \\
\hline 1 & $15-17$ years old & 8 & $6.5 \%$ \\
2 & $18-24$ years old & 88 & $71.0 \%$ \\
3 & $25-29$ years old & 23 & $18.5 \%$ \\
4 & $>30$ years old & 5 & $4.0 \%$ \\
\hline & Total & $\mathbf{1 2 4}$ & $\mathbf{1 0 0 . 0 \%}$
\end{tabular}

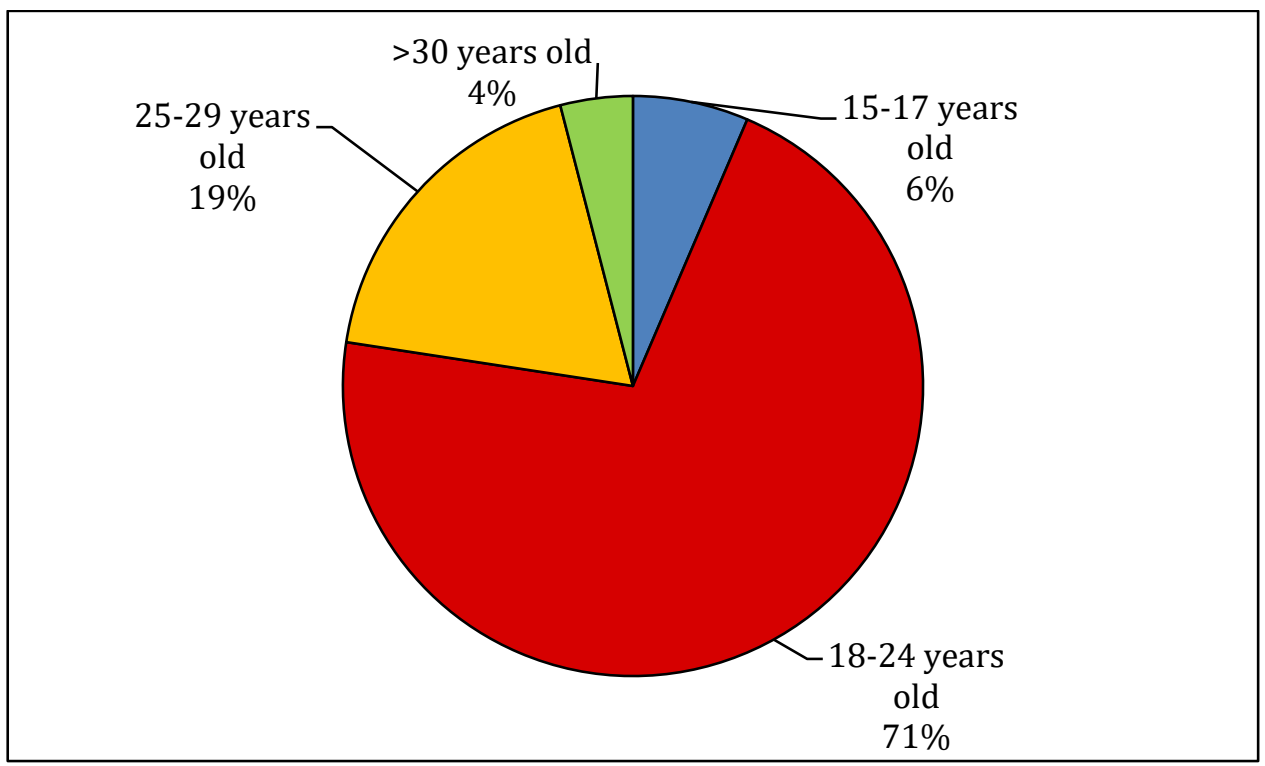

Figure 4. Age Graph of Respondents

The distribution of respondents by gender can be seen in Table 2 above. Based on Table 2 and Figure 4 above, which describes the characteristics of respondents based on age, it can be seen that the largest number of respondents in the study were respondents aged 18-24 as many as 88 people or $71 \%$. For respondents aged 25-29 as many as 23 people or $18.5 \%$, while respondents aged 15-17 were 8 people or $6.5 \%$. The least respondents in this study were respondents aged $>30$ as many as 5 people or by $4 \%$. 


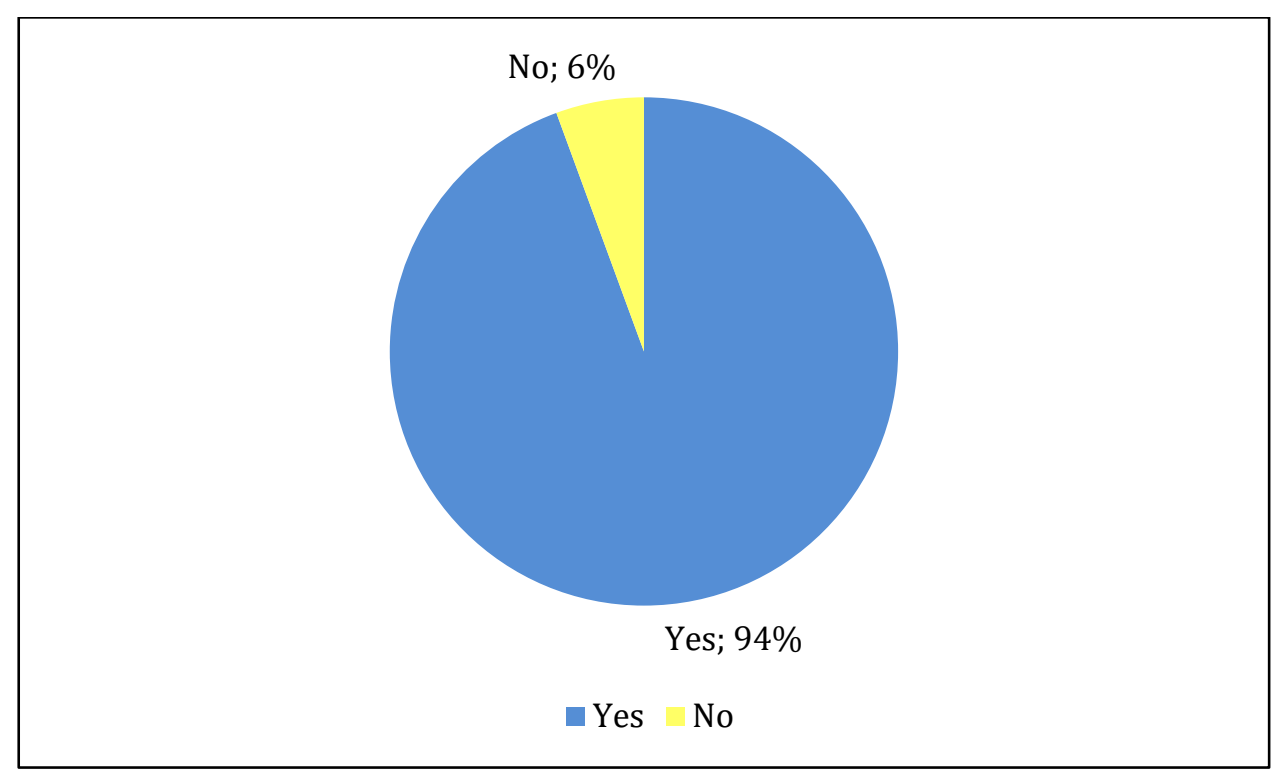

Figure 5. Frequency of Respondents doing Abandonment Shopping Cart

$$
\mathrm{n}=124
$$

Based on Figure 5 above, from 124 respondents, as many as 117 respondents or as many as $94.4 \%$ of respondents have put goods into a shopping cart but they did not checkout. Only 7 respondents or as much as $5.6 \%$ answered that they had never abandoned shopping carts.

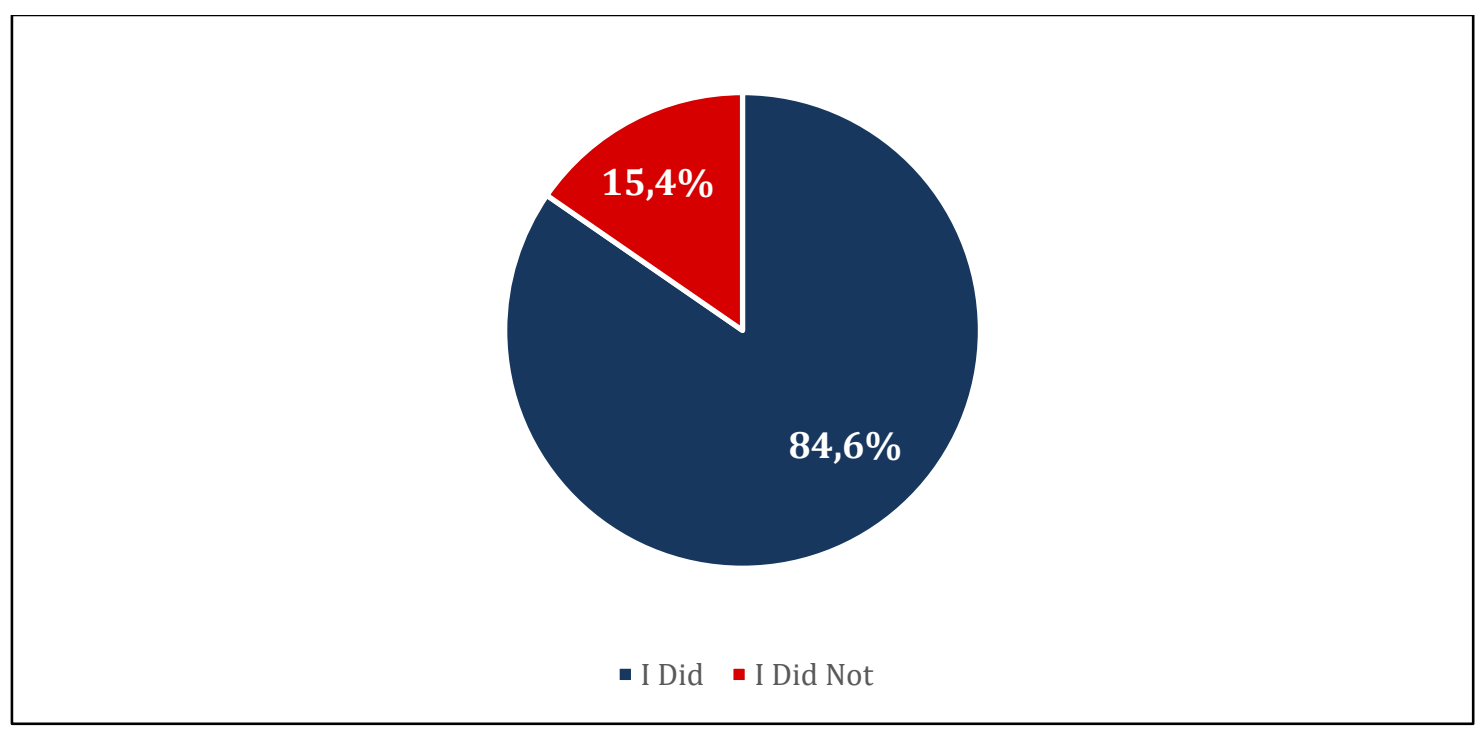

Figure 6. Frequency of Respondents Forgetting to Check Out Items in the Basket

$$
\mathrm{n}=117
$$

Meanwhile, based on Figure 6 above, of the 117 respondents who answered that they had abandoned shopping carts, 99 people or $83.6 \%$ of respondents had forgotten to check out items in the shopping cart, while only 18 people or $16.4 \%$ of respondents answered that they never forgot to checkout. items in the shopping cart. 


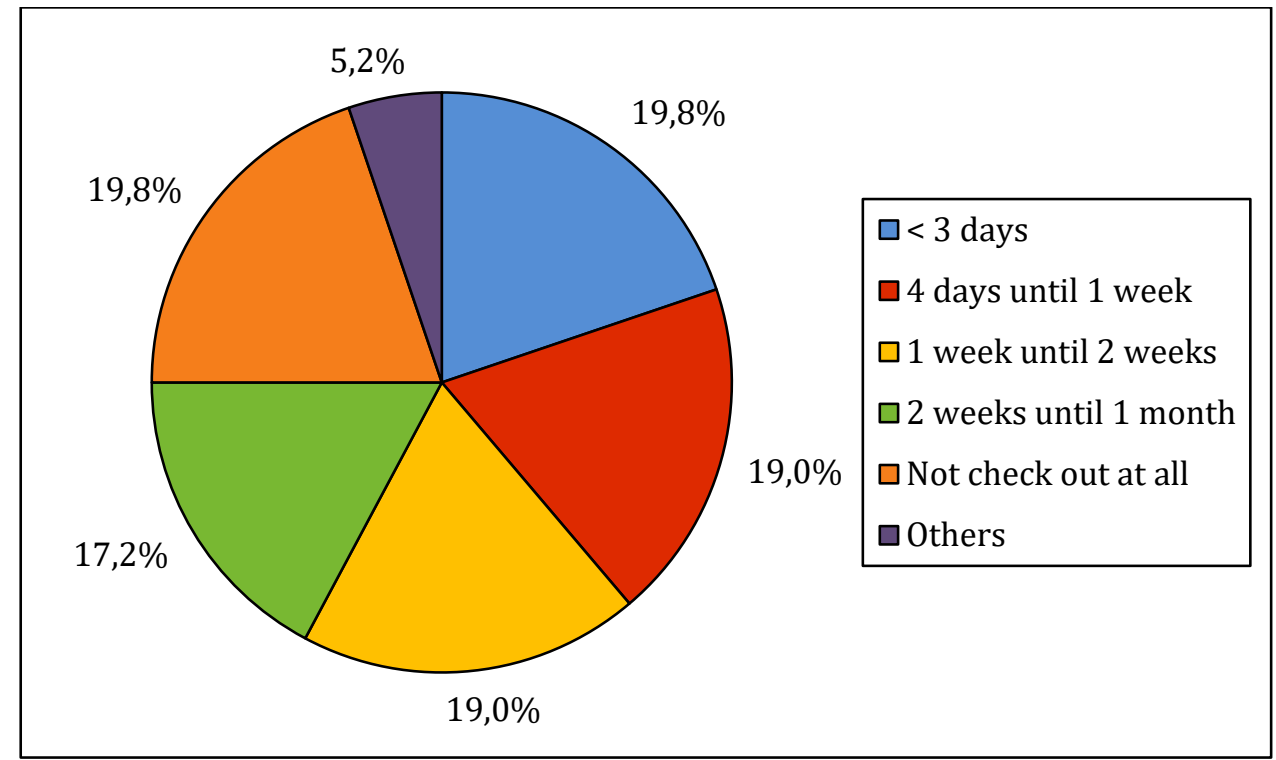

Figure 7. Time Required for Check Out after Shopping Cart Abandonment $n=117$

From Figure 7 about how long it takes respondents to complete a transaction (checkout) after abandoning the shopping cart (abandonment shopping carts), it is found that $19.8 \%$ of respondents answered that they would leave the shopping cart without being checkout for $<3$ days, then checkout. However, as many as $19 \%$ of respondents answered that they usually leave their shopping cart for 4 days to 1 week, 1 week to 2 weeks to finally check out, but $19.8 \%$ of respondents also said that they did not check out goods in the end. As many as $17.2 \%$ of respondents stated that it usually takes them 2 weeks to 1 month to complete a transaction in their shopping cart. However, about $5.3 \%$ of respondents left different answers, some said they remember having to checkout if they wanted to buy the item, sometimes just leave it in the shopping cart to remember what to buy, sometimes some end up at checkout some are cancelled.

Based on 2 indicators regarding Shopping Cart Abandonment, the following is a summary of the respondents' answers:

Table 3. Distribution of Respondents' Answers to Shopping Cart Abandonment

\begin{tabular}{|c|c|c|c|c|c|c|c|}
\hline \multirow{3}{*}{ No. } & \multirow{3}{*}{ Questions } & \multicolumn{5}{|c|}{ Answers } & \multirow{3}{*}{ MEAN } \\
\hline & & $\mathbf{1}$ & 2 & 3 & 4 & 5 & \\
\hline & & VD & D & $\mathbf{N}$ & $\mathbf{A}$ & VA & \\
\hline \multicolumn{8}{|c|}{ Shopping Cart Abandonment } \\
\hline 1 & $\begin{array}{l}\text { I like to put my items in the cart, and I did not } \\
\text { check out the items at the same time }\end{array}$ & 0 & 11 & 18 & 35 & 53 & 4.11 \\
\hline 2 & I like to ignore items in my shopping cart & 2 & 10 & 15 & 38 & 52 & 4.09 \\
\hline \multicolumn{8}{|c|}{ Perceived Cost } \\
\hline 3 & $\begin{array}{l}\text { I am waiting for the store to give a bigger } \\
\text { discount }\end{array}$ & 1 & 9 & 20 & 37 & 50 & 4.08 \\
\hline 4 & $\begin{array}{l}\text { I did not make a purchase after seeing the total } \\
\text { of my shopping cart }\end{array}$ & 6 & 8 & 22 & 38 & 43 & 3.89 \\
\hline 5 & $\begin{array}{l}\text { I didn't buy it when I saw the postage costs for } \\
\text { my order }\end{array}$ & 1 & 7 & 19 & 38 & 53 & 4.14 \\
\hline
\end{tabular}




\begin{tabular}{|c|c|c|c|c|c|c|c|}
\hline \multicolumn{8}{|c|}{ Complicated Checkout } \\
\hline 6 & $\begin{array}{l}\text { Lack of clear instructions for conducting } \\
\text { payments, makes the desire to pay is lost }\end{array}$ & 2 & 17 & 16 & 36 & 46 & 3.91 \\
\hline 7 & $\begin{array}{l}\text { The payment method I want is not available, for } \\
\text { example, few bank transfer options, and others }\end{array}$ & 3 & 17 & 22 & 28 & 47 & 3.85 \\
\hline \multicolumn{8}{|c|}{ Entertainment Motivation } \\
\hline 8 & $\begin{array}{l}\text { I like to browse and pick items at the market } \\
\text { place then put them in the shopping cart for } \\
\text { pleasure }\end{array}$ & 5 & 17 & 18 & 33 & 44 & 3.8 \\
\hline 9 & $\begin{array}{l}\text { I like to browse and pick items at the market } \\
\text { place then put them in the shopping cart when I } \\
\text { feel bored }\end{array}$ & 15 & 12 & 15 & 38 & 37 & 3.6 \\
\hline \multicolumn{8}{|c|}{ Emotional Ambivalence } \\
\hline 10 & $\begin{array}{l}\text { When the item is in the shopping cart, I hesitate } \\
\text { to check out }\end{array}$ & 0 & 12 & 22 & 41 & 43 & 3.98 \\
\hline 11 & I like to put items in the cart based on my mood & 6 & 15 & 32 & 39 & 32 & 3.71 \\
\hline \multicolumn{8}{|c|}{ Information Overload } \\
\hline 12 & $\begin{array}{l}\text { I want to compare the price of the item I want to } \\
\text { buy at other online stores }\end{array}$ & 2 & 7 & 18 & 37 & 53 & 4.13 \\
\hline 13 & $\begin{array}{l}\text { I put several items of the same type into the cart, } \\
\text { to make it easier for me to decide on the best } \\
\text { option when checking out }\end{array}$ & 3 & 3 & 17 & 44 & 50 & 4.15 \\
\hline
\end{tabular}

From Table 3 above, it can be concluded that most respondent's answers stated that they agree with the statements. It can be seen that the average of each statements item has a value above number 3 .
The following is an image of the results of the SEM PLS model using the SmartPLS software.

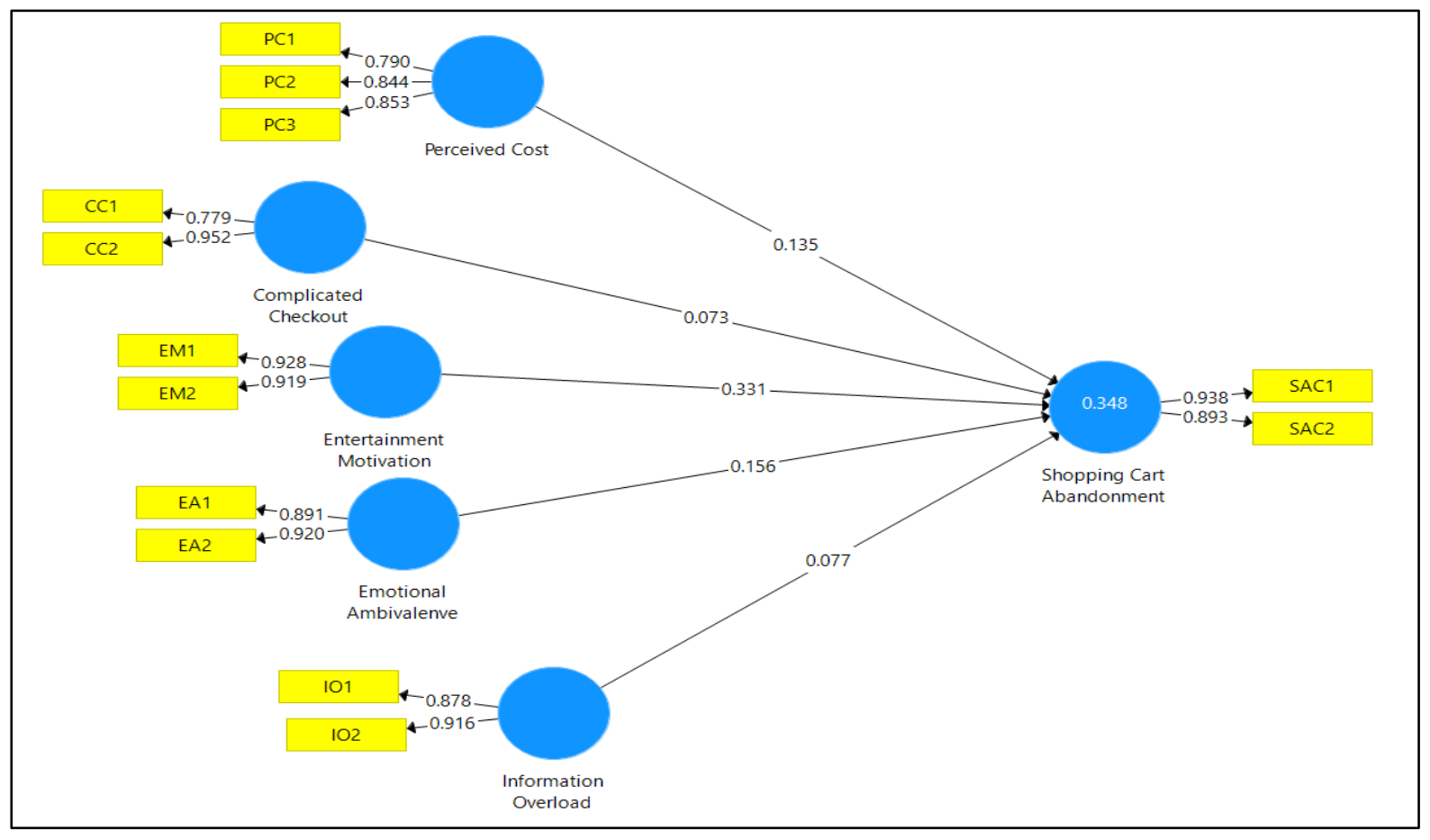

Figure 8. Structural Equation Model 
Table 4. Outer Loading Table Results

Source: Data processed by SmartPLS, 2021

\begin{tabular}{cccc}
\hline Y & $\begin{array}{c}\text { Shopping Cart } \\
\text { Abandonment }\end{array}$ & $\mathbf{X 3}$ & $\begin{array}{c}\text { Entertainment } \\
\text { Motivation }\end{array}$ \\
\hline SAC1 & 0.938 & EM1 & 0.928 \\
\hline SAC2 & 0.893 & EM2 & 0.919 \\
\hline X1 & Perceived Cost & $\mathbf{X 4}$ & $\begin{array}{c}\text { Emotional } \\
\text { Ambivalence }\end{array}$ \\
\hline PC1 & 0.790 & EA1 & 0.891 \\
\hline PC2 & 0.844 & EA2 & 0.920 \\
\hline PC3 & 0.853 & & \\
\hline X2 & $\begin{array}{c}\text { Complicated } \\
\text { Checkout }\end{array}$ & $\mathbf{X 5}$ & $\begin{array}{c}\text { Information } \\
\text { Overload }\end{array}$ \\
\hline CC1 & 0.779 & IO1 & 0.878 \\
\hline CC2 & 0.952 & IO2 & 0.916 \\
\hline
\end{tabular}

Convergent Validity aims to determine the validity of each relationship between the indicator and its latent constructs or variables. According to Hartono \& Abdillah (2014), the loading value of 0.5 to 0.6 is considered sufficient, for the number of latent variables that are not large, between
3-7 variables. Based on Table 4, shows that all variables have a loading value above 0.6 so that the measurement model can be declared good and meets convergent validity and no variables need to be eliminated from the model.

Table 5. Composite Reliability, AVE, and Cronbach Alpha Source: Data processed by SmartPLS, 2021

\begin{tabular}{lccccc}
\hline \multirow{2}{*}{ Construct } & Composite & \multirow{2}{*}{ AVE } & Cronbach & Explanation \\
\cline { 2 - 3 } & Reliability & & Alpha & \\
\hline $\begin{array}{l}\text { Shopping Cart Abandonment } \\
\text { (Y) }\end{array}$ & 0.859934 & 0.756113 & 0.708307 & Good (fit) \\
\hline Perceived Cost (X1) & 0.901229 & 0.820254 & 0.782006 & Good (fit) \\
\hline Complicated Checkout (X2) & 0.920985 & 0.853546 & 0.828547 & Good (fit) \\
\hline Entertainment Motivation (X3) & 0.891838 & 0.804858 & 0.759225 & Good (fit) \\
\hline Emotional Ambivalence (X4) & 0.868514 & 0.687913 & 0.773640 & Good (fit) \\
\hline Information Overload (X5) & 0.911995 & 0.838307 & 0.810110 & Good (fit) \\
\hline
\end{tabular}

Discriminant Validity is carried out to ensure that each concept of each model is different from other variables. By comparing the square root value of the average variance extracted (AVE) independently between other variables in the model, if the value of the AVE variable is greater than the display with all other variables, it is declared to have good discriminant validity. According to Fornell \& Larcker (1981), a good discriminant validity is AVE $>0.5$. 
Based on Table 5 above, all latent variables have an AVE value above 0.5 , so there is no discriminant validity problem in the model being tested, the model is considered good, and meets the goodness of fit criteria.

Table 6. Fornell-Larcker Criterion

Source: Data processed by SmartPLS, 2021

\begin{tabular}{|c|c|c|c|c|c|c|}
\hline & $\mathbf{C C}$ & EA & EM & IO & PC & SCA \\
\hline $\begin{array}{l}\text { Complicated } \\
\text { Checkout }\end{array}$ & 0.870 & 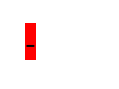 & 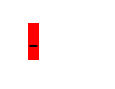 & 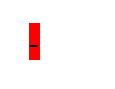 & | & 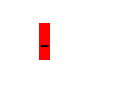 \\
\hline $\begin{array}{l}\text { Emotional } \\
\text { Ambivalence }\end{array}$ & 0.240 & 0.906 & 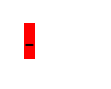 & I & | & 1 \\
\hline $\begin{array}{l}\text { Entertainment } \\
\text { Motivation }\end{array}$ & 0.310 & 0.599 & 0.924 & 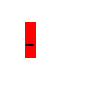 & | & 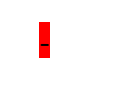 \\
\hline $\begin{array}{l}\text { Information } \\
\text { Overload }\end{array}$ & 0.310 & 0.357 & 0.314 & 0.897 & | & 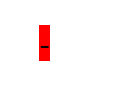 \\
\hline Perceived Cost & 0.191 & 0.523 & 0.433 & 0.460 & 0.829 & 1 \\
\hline $\begin{array}{l}\text { Shopping Cart } \\
\text { Abandonment }\end{array}$ & 0.263 & 0.470 & 0.530 & 0.321 & 0.409 & 0.916 \\
\hline
\end{tabular}

Based on Table 6, each number in bold is the result of the AVE root value of each construct and the undressed number is the correlation value between constructs and other constructs in the model. It can be concluded that, based on the results of Tables 5 and 6 above, all constructs have met the criteria for discriminant validity.

The next test is to calculate the reliability of the indicator. Composite Reliability is to measure the real reliability value of a variable, while Cronbach-alpha measures the lowest (lowerbound) value of the reliability of a variable. According to Hartono \& Abdillah, (2014), the requirement for alpha value or composite reliability must be greater than 0.7 , although a value of 0.6 is still acceptable (Hair et al., 2014).

Based on Table 5, it can be seen that all reliable constructs, both composite reliability and Cronbach's alpha, have a value above 0.7. So, all constructs have good reliability values following the required minimum limits.

The value of $\mathrm{R}$ square shows the level of determination of the independent variable on the dependent variable. The greater the Rsquare value, the better the determination value.

Table 7. R-Square Value

Source: Data processed by SmartPLS, 2021

\begin{tabular}{lcc}
\hline & R Square & R Square Adjusted \\
\hline Shopping Cart Abandonment & 0.348 & 0.318 \\
\hline
\end{tabular}

Based on Table 7 above, the R-Square value is 0.348 for the Abandonment Shopping Cart construct. This means that the variables perceived cost, complicated checkout, entertainment motivation, emotional ambivalence, and information overload can 
explain the shopping cart abandonment variable by $34.8 \%$, the remaining $65.2 \%$ is explained by other factors.

\section{Hypothesis Testing (Bootstrapping)}

To conclude that $\mathrm{H} 0$ is accepted or rejected, pvalue is used with a significance of $\alpha=5 \%$ or
0.05 . If the $\mathrm{p}$-value $<0.05$ then $\mathrm{H} 0$ is rejected or $\mathrm{H} 1$ is accepted, which means that there is a significant influence between these variables. If the p-value $>0.05$ then $\mathrm{H} 0$ is accepted or $\mathrm{H} 1$ is rejected, which means that there is no significant influence between these variables. The following is the result of the estimation output for structural sample testing.

Table 8. Path Coefficients

\begin{tabular}{lccccc}
\hline & $\begin{array}{l}\text { Original } \\
\text { Sample (O) }\end{array}$ & $\begin{array}{l}\text { Sample } \\
\text { Mean (M) }\end{array}$ & $\begin{array}{l}\text { Standard } \\
\text { Deviation } \\
\text { (STDEV) }\end{array}$ & $\begin{array}{l}\text { T Statistics } \\
(|\mathbf{O S T D E V}|)\end{array}$ & P Values \\
\hline $\begin{array}{l}\text { Complicated Checkout -> } \\
\text { Shopping Cart } \\
\text { Abandonment }\end{array}$ & 0.073 & 0.083 & 0.085 & 0.864 & $\mathbf{0 . 3 8 8}$ \\
\hline $\begin{array}{l}\text { Emotional Ambivalence -> } \\
\text { Shopping Cart } \\
\text { Abandonment }\end{array}$ & 0.156 & 0.160 & 0.136 & 1.145 & $\mathbf{0 . 2 5 3}$ \\
\hline $\begin{array}{l}\text { Entertainment Motivation -> } \\
\text { Shopping Cart }\end{array}$ & 0.331 & 0.320 & 0.133 & 2.496 & $\mathbf{0 . 0 1 3}$ \\
Abandonment & & & & & \\
\hline $\begin{array}{l}\text { Information Overload -> } \\
\text { Shopping Cart } \\
\text { Abandonment }\end{array}$ & 0.077 & 0.094 & 0.093 & 0.833 & $\mathbf{0 . 4 0 5}$ \\
\hline $\begin{array}{l}\text { Perceived Cost -> Shopping } \\
\text { Cart Abandonment }\end{array}$ & 0.135 & 0.141 & 0.119 & 1.127 & $\mathbf{0 . 2 6 0}$ \\
\hline & & & & & \\
\hline
\end{tabular}

Table 9. Hypothesis Test Results

Source: Data processed by SmartPLS, 2021

\begin{tabular}{cll}
\hline \multirow{2}{*}{ Hypothesis } & Null Hypothesis & H0 $: \boldsymbol{\beta} \mathbf{k}=0$ \\
\cline { 2 - 3 } & Alternative Hypothesis & H0 $: \boldsymbol{\beta} \neq \mathbf{0}$ \\
\hline \multirow{2}{*}{ Decision Rules: } & Hypothesis H0 denied if $(\mathrm{P}>|\mathrm{t}|)<0.05(\boldsymbol{\alpha})$ or t-stat $<$ t-critical
\end{tabular}

Decision Rules: Hypothesis H0 denied if $(\mathrm{P}>|\mathrm{t}|)<0.05(\alpha)$ or $\mathrm{t}$-stat $<\mathrm{t}$-critical

\begin{tabular}{lcccccc}
\hline & $\begin{array}{c}\text { Original } \\
\text { Sample (O) }\end{array}$ & $\begin{array}{c}\text { Sample } \\
\text { Mean (M) }\end{array}$ & $\begin{array}{c}\text { Standard } \\
\text { Deviation }\end{array}$ & $\begin{array}{c}\text { T } \\
\text { Statistics }\end{array}$ & P Values & Result \\
\hline PC -> SCA & 0.135 & 0.141 & 0.119 & 1.127 & 0.260 & Not Significant \\
\hline CC -> SCA & 0.073 & 0.083 & 0.085 & 0.864 & 0.388 & Not Significant \\
\hline EM -> SCA & 0.331 & 0.320 & 0.133 & 2.496 & 0.013 & Significant \\
\hline EA -> SCA & 0.156 & 0.160 & 0.136 & 1.145 & 0.253 & Not Significant \\
\hline IO -> SCA & 0.077 & 0.094 & 0.093 & 0.833 & 0.405 & Not Significant \\
\hline
\end{tabular}

The level of significance $(\alpha) 5 \%$ 
Based on Table 9 above, to calculate the significance between the independent variables (PC, CC, EM, EA, IO) on the dependent variable (SCA) using t-statistics.

The interpretation of the regression results is as follows:

a. The regression coefficient on the PC variable (Perceived Cost) of +0.135 indicates a direct relationship with shopping cart abandonment. When the PC (Perceived Cost) increases by one unit, assuming ceteris paribus on the independent variable, the shopping cart abandonment value will increase by 0.135 or $13.50 \%$.

b. The regression coefficient on the $\mathrm{CC}$ (Complicated Checkout) variable is +0.073 indicating a direct relationship with shopping cart abandonment. When the CC (Complicated Checkout) increases by one unit, assuming ceteris paribus on the independent variable, the shopping cart abandonment value will increase by 0.073 or $7.3 \%$.

c. The regression coefficient on the EM (Entertainment Motivation) variable is + 0.331, indicating a unidirectional relationship with shopping cart abandonment. When EM (Entertainment Motivation) increases by one unit, assuming ceteris paribus on the independent variable, the value of shopping cart abandonment will increase by 0.331 or $33.1 \%$.

d. The regression coefficient on the EA (Emotional Ambivalence) variable is +0.156 , which indicates a unidirectional relationship with shopping cart abandonment. When EA (Emotional Ambivalence) increases by one unit with the assumption of ceteris paribus on the independent variable, the value of shopping cart abandonment will increase by 0.156 or $15.6 \%$.

e. The regression coefficient on the IO (Information Overload) variable is +0.077 , indicating a direct relationship with shopping cart abandonment. When the IO (Information Overload) increases by one unit, assuming ceteris paribus on the independent variable, the shopping cart abandonment value will increase by 0.077 or $7.7 \%$.

\section{Effect of Perceived Cost on Shopping Cart Abandonment}

The first hypothesis says that perceived cost will have a positive effect on shopping cart abandonment. This means that if the Perceived cost increases, it will result in an increase in shopping cart abandonment. The increase in perceived cost is due to factors such as discounting of goods, shipping costs which will affect the total expenditure as a whole which will affect consumer interest in buying an item. Consumers will see the total price as a whole when considering whether to checkout or not. With the consumer's consideration when looking at the total price, the consumers are more likely to organize and research the products in their basket and increase their probability of waiting for the price of the goods to be cheaper. So that the greater the total price that must be issued, will cause an increase in shopping. cart abandonment is increasing. The results of this study are supported by previous research, namely (Wu, Chen, Chen, and Cheng, 2014), (Xu, 2015), (Kukar-Kinney and Close 2010), in Xu's research (2015) it was stated that perceived cost had no significant effect on shopping. cart abandonment.

\section{Effect of Complicated Checkout Process on Shopping Cart Abandonment}

The second hypothesis states that the complicated checkout process will have a positive effect on shopping cart abandonment. This means that if the Complicated checkout process increases, it will result in an increase in shopping cart abandonment. A complicated checkout process will influence consumers to complete the transaction. The more complicated the checkout process stages that must be carried out, the more reluctant 
consumers will be to complete the transaction, which results in increased shopping cart abandonment. A complicated checkout process can be caused by several things: 1). The complexity at checkout related to data security such as entering card numbers, telephone numbers, and personal identities will also influence consumers to complete purchase transactions, the more consumers feel that their data is threatened, the more reluctant consumers are to complete the transaction, thus increasing shopping cart abandonment. 2). The limited choice of payment transactions, such as few bank transfer options, no payment options via e-wallet, or payment through the nearest mini-market can also affect the consumer's decision to complete the transaction. If consumers do not checkout, shopping cart abandonment will increase. The results of this study are consistent with previous research, namely Rajamma (2009) and Cho (2006).

\section{Effect of Entertainment Motivation on Shopping Cart Abandonment}

The third hypothesis says that Entertainment Motivation will have a positive effect on shopping cart abandonment. This means that if Entertainment Motivation increases, it will result in an increase in shopping cart abandonment. One of the reasons consumers shop online is to fulfil their satisfaction. From online shopping, consumers will get entertainment value by having fun by browsing the items in the marketplace and then entering the items of interest into the shopping cart. Online shopping can also be a tool to get rid of boredom. The number of items left in the shopping cart for fun and relieve boredom, if they choose not to buy these items, shopping cart abandonment will increase. The results of this study are consistent with previous research, namely Kukar-Kinney (2009).
Effect of Emotional Ambivalence on Shopping Cart Abandonment

The fourth hypothesis states that Emotional Ambivalence will have a positive effect on shopping cart abandonment. This means that if emotional ambivalence increases, it will result in an increase in shopping cart abandonment. When shopping online, there are times when consumers feel doubt about the choice of items that have been previously added to the shopping cart. So that this doubt will have a negative effect on consumers which will influence consumer decisions. Apart from feelings of doubt, negative effects can also be caused by a bad experience from previous shopping. All of these emotions cause emotional ambivalence which causes consumers to enter goods into the shopping cart, but there is still a possibility that the consumer will not complete the shopping transaction (checkout). This result is in accordance with previous research, namely Huang (2018).

\section{Effect of Information Overload on Shopping Cart Abandonment}

The fifth hypothesis states that Information Overload over the Product will have a positive effect on shopping cart abandonment. This means that if Information Overload over the Product increases, it will result in an increase in shopping cart abandonment. One of the consumers behavior that is most often done is comparing prices in order to get the price that best matches the desire to pay for an item. Consumers tend to compare prices in one marketplace with another. In addition to online stores, consumers will also compare prices at conventional retail stores if consumers feel that the available website is unreliable. As a result of a large amount of information available, there will be delays in check out, resulting in increased shopping cart abandonment. The results of this study are consistent with previous research, namely Cho (2006). 


\section{Conclusions and Suggestions}

Based on the results of the Regression Equation Feasibility Test (Goodness of Fit), it can be concluded as follows; Perceived Cost (PC) has a positive and insignificant effect on shopping cart abandonment, Complicated Checkout (CC) has a positive and insignificant effect on shopping cart abandonment, Entertainment Motivation (EM) has a positive and significant effect on shopping cart abandonment, Emotional ambivalence (EA) has a positive and insignificant effect on shopping cart abandonment, meanwhile Information Overload (IO) has a positive and insignificant effect on shopping cart abandonment It can be concluded that the variable that has the most significant influence on shopping cart abandonment comes from Entertainment Motivation (EM).

Based on the results of the research and discussion that has been stated, with the small number of studies that discuss shopping cart abandonment, there are still many suggestions for further research in order to provide more complete, up-to-date, and accurate contribution results. Further research should be able to increase the number of samples and question items. Based on the R-Square value, which is 0.348 for the Abandonment Shopping Cart construct. Which means the variables perceived cost, complicated checkout, entertainment motivation, emotional ambivalence, and information overload can explain the shopping cart abandonment variable by $34.8 \%$, the remaining $65.2 \%$ is explained by other factors. The research variables can also be added by paying attention to consumer behaviour in Indonesia, seeing that the era of online buying in Indonesia still has a very large development opportunity.

From this research there are some limitations that can be improve for future research, first of all the number of samples (questionnaires) is limited, which causes the accuracy of the results to be lower.
Second, the number of research items is still small, so it still does not represent the independent and dependent variables. Last but not least, the number of previous studies on shopping cart abandonment is still small, causing the reference of this study to be narrow.

\section{References}

Cho, J. (2004). Likelihood to abort an online transaction: influences from cognitive evaluations, attitudes, and behavioral variables. Information and Management, 41(7), pp. 827-838.

Cho, V. (2006). A study of the roles of trusts and risks in information-oriented online legal services using an integrated model. Information \& Management, 43(4), pp. 502-520. https://doi.org/10.1016/j.im.2005.12.0 02

Close, A. G., \& Kukar-Kinney, M. (2010). Beyond buying: motivations behind consumers' online shopping cart use. Journal of Business Research, 63(910), pp. 986-992. https://doi.org /10.1016/j.jbusres.2009.01.022

Fornell, C., Larcker, D. F. (1981). Structural equation models with unobservable variables and measurement error: algebra and statistics. Journal of Marketing Research, 18(3), pp. 382-388. https://doi.org/10.1177/002224378101 800313

Hair Jr, J. F., Sarstedt, M., Hopkins, L., Kuppelwieser, V. G. (2014). Partial least squares structural equation modeling (PLS-SEM). European Business Review, 26(2), pp. 106-121. https://doi.org/10.1108/EBR-10-20130128

Hartono, J., \& Abdillah, W. (2014). Konsep dan aplikasi (Partial Least Square) untuk penelitian empiris (1st ed.). Yogyakarta: BPFE UGM. 
Huang, G. H., Korfiatis, N., \& Chang, C. T. (2018). Mobile shopping cart abandonment: the roles of conflicts, ambivalence, and hesitation. Journal of Business Research, 85, pp. 165-174. https://doi.org/10.1016/j.jbusres.2017. 12.008

Kukar-Kinney, M., \& Close, A. G. (2009). The determinants of consumers' online shopping cart abandonment. Journal of the Academy of Marketing Science, 38(2), pp. 240-250. https://doi.org/10. 1007/s11747-009-0141-5

Novak, T., Hoffman, D. \& Yung, Y. (2000). Measuring the customer experience in online environments: a structural modeling approach. Marketing Science. 19(1), pp. 22-42. https://doi.org/10.1287/mksc.19.1.22.1 5184

Opiida (2014). Pengertian e-marketplace, Retrieved from https://tokokhalista.wordpress.com/20 14/04/18/pengertian-e-marketplace/

Rajamma, R. K., Paswan, A. K., \& Hossain, M. M. (2009). Why do shoppers abandon shopping cart? perceived waiting time, risk, and transaction inconvenience. Journal of Product and Brand Management, 18(3), pp. 188197.

https://doi.org/10.1108/106104209109 57816

Wolfinbarger, M., \& Gilly, M. C. (2001). Shopping online for freedom, control, and fun. California Management Review, 43(2), pp. 34-55. https://doi.org/10.2307/41166074

Wu, L., Chen, K., Chen, P., \& Cheng, S. (2014). Perceived value, transaction cost, and repurchase-intention in online shopping: a relational exchange perspective. Journal of Business Research. 67(1) pp. 2768-2776. https://doi.org/10.1016/j.jbusres.2012. 09.007
Xia, L., Monroe, K. B., \& Cox, J. L. (2004). The price is unfair! a conceptual framework of price fairness perceptions. Journal of Marketing, 68(4), pp. $1-15$. https://doi.org/10.1509/jmkg.68.4.1.42 733

Xu, Y., \& Huang, J. S. (2015). Factors influencing cart abandonment in the online shopping process. Social Behavior and Personality, 43(10), pp. 1617-1628. 